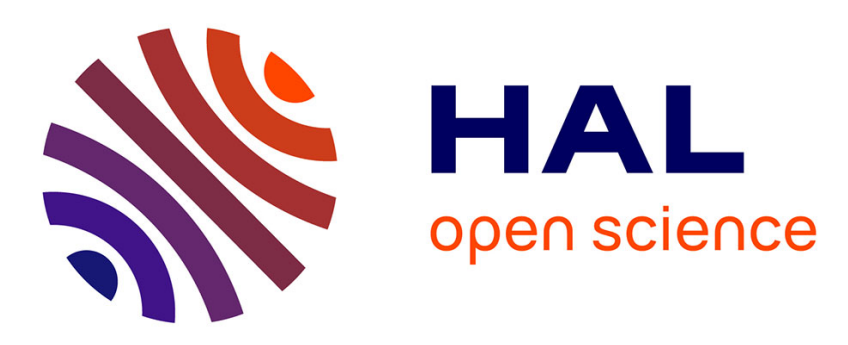

\title{
Combining indicators for decision making in planning issues: A theoretical approach to perform sustainability assessment
}

Vincent Hely, Jean-Philippe Antoni

\section{- To cite this version:}

Vincent Hely, Jean-Philippe Antoni. Combining indicators for decision making in planning issues: A theoretical approach to perform sustainability assessment. Sustainable Cities and Society, 2019, 44, pp.844-854. 10.1016/j.scs.2018.10.035 . hal-01931166

\section{HAL Id: hal-01931166 https://hal.science/hal-01931166}

Submitted on 26 Nov 2018

HAL is a multi-disciplinary open access archive for the deposit and dissemination of scientific research documents, whether they are published or not. The documents may come from teaching and research institutions in France or abroad, or from public or private research centers.
L'archive ouverte pluridisciplinaire HAL, est destinée au dépôt et à la diffusion de documents scientifiques de niveau recherche, publiés ou non, émanant des établissements d'enseignement et de recherche français ou étrangers, des laboratoires publics ou privés. 


\section{Combining indicators for decision making in planning issues}

A theoretical approach to perform sustainability assessment

Vincent Hély - vincenthely@hotmail.fr

Jean-Philippe Antoni - jean-philippe.antoni@u-bourgogne.fr

Laboratoire ThéMA, UMR 6049 French National Centre of Scientific Research (CNRS), University of Bourgogne-Franche-Comte

This is a postprint version, the definitive version of this paper has been published in Sustainable Cities and Society, 44, 2019-01.

DOI : 10.1016/j.scs.2018.10.035 


\title{
Combining indicators for decision making in planning issues
}

\author{
A theoretical approach to perform sustainability assessment
}

\author{
Vincent Hély ${ }^{1}$ and Jean-Philippe Antoni ${ }^{1}$ \\ ${ }^{1}$ Laboratoire ThéMA
}

\begin{abstract}
In order to achieve sustainability objectives, spatial modeling and simulations dedicated to land and urban planning are increasingly useful for producing prospective scenarios to guide stakeholder decisions and actions. These scenarios are usually assessed by way of numerous economic, social, and environmental indicators, but they are rarely combined within a synthetic approach for global assessment and scenario comparison. From an example applied to the Greater Besançon area, this paper presents a methodology for generating synthetic indicators. The paper is innovative in that it proposes a method for combining such indicators. This consists of three steps : (i) evaluation, (ii) aggregation, and (iii) combination, leading to decision support for decision-making. Based on this method, a grid analysis map of the study area (Besançon) is produced from which the strengths and weaknesses of the territory can be identified in terms of sustainability. The resulting maps are relevant and useful, although they inevitably raise some fundamental and theoretical questions about the implementation of sustainable development principles at the scale of an urban region. These are discussed in the conclusion with news maps.
\end{abstract}

Keywords : Sustainable city, Urban planning, Decision support systems, Multicriteria analysis, 
Even if relevant indicators have abounded in the three spheres of sustainable development to identify possible investment strategies and improve cities' livability, viability, and equity, a major difficulty now is to harmonize and interweave them. The construction of global indicators can help to evaluate and to make decisions from analysis and scenario simulations. The definition of global indicators, synthesizing all others, is therefore a current subject of discussions and several studies have been published on this topic in recent decades ([PAMS04]; [RFD06]; [HWY15]; [KLM15]). Consequently, a whole array of sectoral elementary indicators has been drawn on to evaluate local territorial performances of sustainability complying with various criteria as for instance in the Propolis European report $\left(\left[\mathrm{LSW}^{+} 04\right]\right)$.

Moreover, to render these indicators more useful for decision-making, many works have tried to establish conceptual guidelines, essentially in the field of decision support systems (DSS), designed as computerized information systems to support decision-making activities ([BH08]; GC08]; $\left.\mathrm{MRP}^{+} 14\right]$ ). This is not the place for a detailed review of the different types of DSS, but we emphasize that in their latest developments, techniques for the treatment of indicators have been greatly improved. In particular, methodologies based on multi-criteria analysis (such as the ELECTRE method)(|Roy85])and analytic hierarchy processes (AHP) ([Saa90]) are used to aggregate multiple indicators, while enabling prioritization and/or weighting according to their importance for decision-makers. More accurately, the multicriteria spatial decision support system (MC-DSS) ([Mal99]) explicitly integrates the spatial dimension and involves both geographical data and decision-makers' preferences according to specified rules ([Mal06]). Furthermore, multiactor multicriteria analysis (MAMCA) ([MWT13]) provides another tool for constructing composite indicators by normalizing and aggregating elementary indicators ([Mun05]; [ZA08] ; CCK14] [DY15]). Such methodologies can be used in assessing local territorial performances in accordance with the three spheres of sustainable development, but also with the environmental specificities of each case study ([LLH $\left.{ }^{+} 09\right]$; [FP12]; [FP13] [GDJ 13] ; $\left[\mathrm{GGB}^{+} 16\right],\left[\mathrm{BMP}^{+} 18\right]$ ). This work enables us to identify the value of a multi-criteria evaluation approach for conducting a sustainable development policy while at the same time it shows the difficulties of actually implementing this complex theoretical approach.

Two major limitations currently emerge from these promising works. First, in terms of methodology, the production of synthetic indicators raises the question of their combination rates and the production of information about their performance on a whole and complex study area in keeping with sustainability requirements. Second, from a practical standpoint, the problem remains 
of developing a method that is both scientifically rigorous and comprehensive enough for scientists and decision-makers alike. These two points are inevitably linked [APL18]. They require an appropriate, comprehensive and effective method, regardless of the specificities of the study area. We assume that such a method could satisfy the objectives of "good governance" and generate synthetic data that is readable and usable both by decision-makers and scientists for sustainable planning issues ([Bou10]).

\subsection{Objectives}

Beginning with this assumption, this paper focuses on a methodological approach for characterizing territories at a local scale, according to the synthesis of their social, economic, and environmental performances. This method combines scientific rigor (choice of indicators), expert opinion (evaluation of indicators), and end-users participation (aggregation of indicators) ([FDM $\left.{ }^{+} 06\right]$; Ree05]).Its main objective is to propose a methodological process for evaluating and analyzing a territory in terms of its sustainable development requirements. The paper's main contribution is a method proposed to combine such indicators. It breaks down into three central steps : (i) evaluation, (ii) aggregation, and (iii) combination. Based upon the background previously identified, in particular concerning the aggregation of indicators, we propose to go further by constructing a combination leading to a single synthetic indicator capable of categorizing urban and regional spaces according to their characteristics. For this we adopt a simplified means of aggregation in the methodological process compared with other existing methods. This is meant to provide subsequently an innovative combination stage revealing a spatial analysis of the sustainability of the territory that can be reproduced over different types of spaces. As has been done for other synthetic indicators ([YD10]), this work uses grid mapping. The approach is original in that it uses a combinatorial method, which consists in determining the overall performance of a cell by combining its respective performances (synthetic indicators) in each sphere of sustainability. Presented in the form of a map, this final indicator can be easily read by decision-makers, and used for discussing planning policy. The method should also be capable of involving the different actors in a planning project at each step, so as to provide a complete prototype tool for decision support. Here it is applied to a case study of Greater Besançon. 


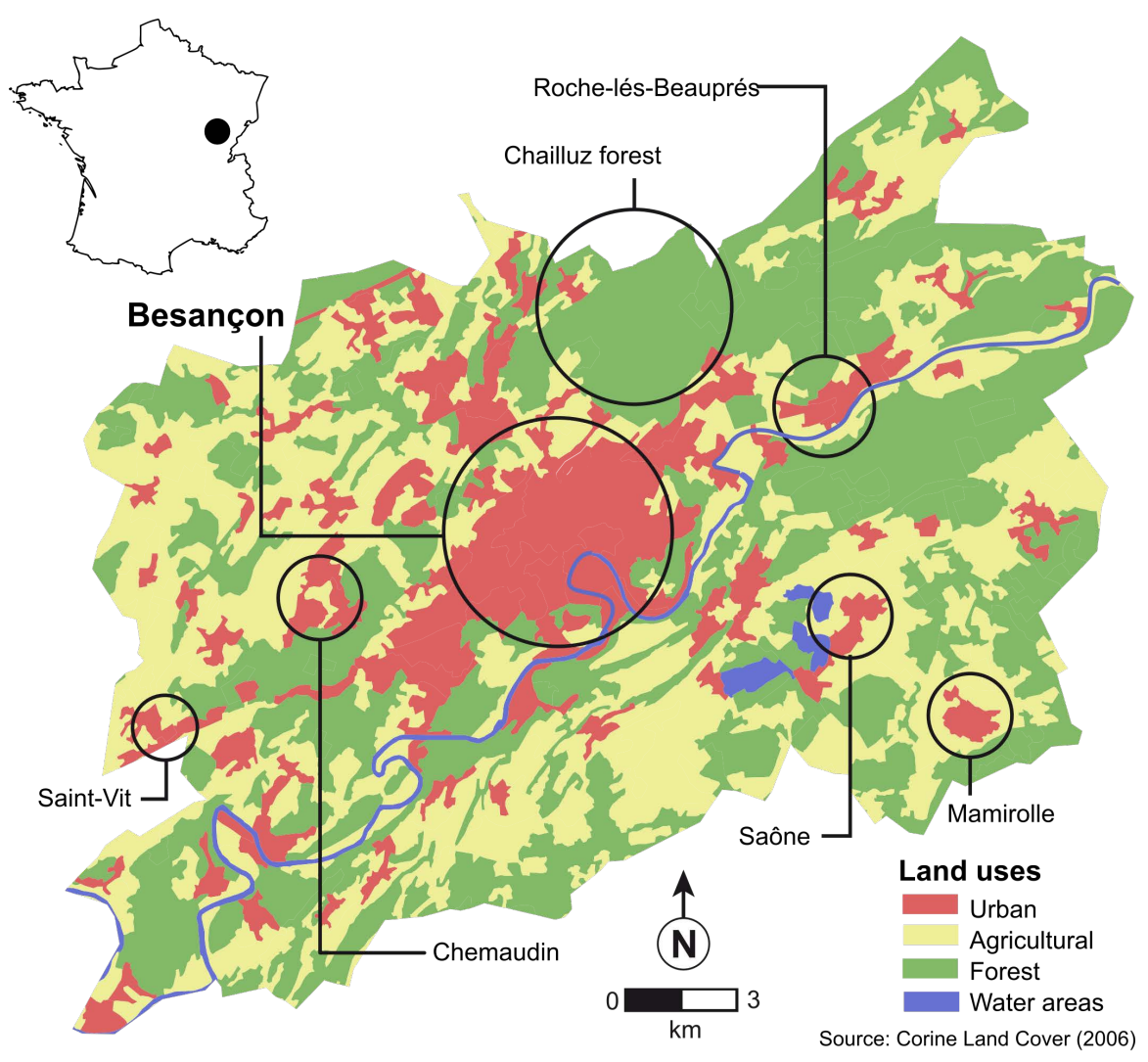

Figure 1 - Study area : land uses in Greater Besançon

\section{Data and material}

\subsection{Study area and data}

The study area is the urban region of Besançon known as Greater Besançon (Grand Besançon), in eastern France (Figure 1). Greater Besançon is an "intercommunal" authority with responsibility for a range of policy areas including planning and transport. This urban region is located on the edge of the Jura Mountains and includes a core city (117,000 inhabitants) managed by a local authority (Ville de Besançon) surrounded by residential areas with low population densities spread across 58 smaller local authority areas.

For about a decade now, Greater Besançon has been studied using the MobiSim simulation platform ([AV10]; ALV16]; [THS $\left.{ }^{+} 16\right]$ ). MobiSim is an agent-based simulation tool for geographical analysis of daily and residential mobility dynamics. It supports decision-making for sustainable planning 
of French and European cities. MobiSim simulates realistic prospective scenarios of spatial change. These scenarios encompass changes in a global context (e.g. demographic change, energy costs, household incomes), a local context (e.g. creation of transport infrastructure, new planning rules), and in terms of behavior (e.g. residential household preferences, modal choice preferences). Further information about the MobiSim project and the indicators produced by the model is available at ww.mobisim.org.

From the MobiSim results calculated under a "business as usual" scenario for $2016\left(\left[\mathrm{ABF}^{+} 14\right]\right)$, three elementary indicators by sphere $(3 * 3=9)$ were chosen for their relevance to sustainable development, based on different fields of literature ([Mun05]; [BM08]; [ZA08]; [MWT13]). The selection and the number of indicators is voluntarily limited to facilitate the theoretical demonstration and does not claim to be an absolute reference. It will not be discussed in this paper.

\subsection{Sustainability indicators}

Figure 2 presents the selected indicators. They are all calculated, aggregated, and displayed within a GIS grid composed of regular square cells with sides of 400 meters. These grid cells allow results to overlap and can be considered as local parts of the entire territory. They can be used to compare local performances for each of the nine indicators. These indicators are derived from MobiSim input data. These inputs were initially based on databases provided by different French public institutes, such as INSEE $4^{4}$ and IGN $5^{5}$

\section{Methods}

As shown in Figure 3, the methodology proposed for combining indicators is composed of three major steps : (1) evaluation, (2) aggregation, and (3) the combination of indicators, leading to (4) a prototype decision support system for planning issues. Points (1), (2), and (3) are described in this section. The discussion of the results, in section 5, addresses issues relating to (4).

4. Institut national de la statistique et des études économiques (www.insee.fr).

5. Institut géographique national (www.ign.fr). 


\begin{tabular}{|c|c|c|c|}
\hline Sphere & Code & Name & Description \\
\hline \multirow{3}{*}{$\begin{array}{l}\text { Economic } \\
\text { indicators } \\
(\mathrm{ECO})\end{array}$} & 1.1 & Travel costs & $\begin{array}{l}\text { Calculates the generalized cost (texteuro) from a point to all others (by route) for all } \\
\text { transportation modes, and determines the most attractive (less expensive) mode for } \\
\text { each different location }\end{array}$ \\
\hline & 1.2 & $\begin{array}{l}\text { Transport } \\
\text { performance }\end{array}$ & $\begin{array}{l}\text { Determines the areas fast connected (time-distance) by public transports and "soft } \\
\text { modes" (walking and biking) compared with private cars }\end{array}$ \\
\hline & 1.3. & Jobs availbility & $\begin{array}{l}\text { Determines the time-distance necessary to reach the } 100 \text { nearest jobs in the } \\
\text { neighborhood from each place of residence }\end{array}$ \\
\hline \multirow{3}{*}{$\begin{array}{l}\text { Social } \\
\text { indicators } \\
(\mathrm{SOC})\end{array}$} & 2.1. & Diversity index & $\begin{array}{l}\text { Determines the heterogeneity of the population of a place }(400 \mathrm{~m} \text { cells), compared } \\
\text { with its composition for the whole study area, on the basis of the Shannon index }\end{array}$ \\
\hline & 2.2 & Segregation index & $\begin{array}{l}\text { Determines the proportion of unemployed people in a place }(400 \mathrm{~m} \text { cells) according } \\
\text { to the unemployment rate of the whole study area }\end{array}$ \\
\hline & 2.3 & $\begin{array}{l}\text { Accessibility to } \\
\text { amenities }\end{array}$ & Evaluates the number of local shops and services availablewithin a $400 \mathrm{~m}$ radius \\
\hline \multirow{3}{*}{$\begin{array}{l}\text { Environmental } \\
\text { indicators } \\
(\mathrm{ENV})\end{array}$} & 3.1 & $\begin{array}{l}\text { Proximity to green } \\
\text { spaces }\end{array}$ & $\begin{array}{l}\text { Evaluates the quality of the landscape in terms of proximity to parks and forests, by } \\
\text { calculating the proportion of green spaces in a local neighborhood of } 400 \mathrm{~m} \text {. }\end{array}$ \\
\hline & 3.2 & Agricultural impacts & $\begin{array}{l}\text { Identifies residential spill-over areas (ha) from the proportion of farmland } \\
\text { surrounding a built-up zone within a } 400 \mathrm{~m} \text { radius }\end{array}$ \\
\hline & 3.3 & $\begin{array}{l}\text { Atmospheric } \\
\text { pollution }\end{array}$ & $\begin{array}{l}\text { Assesses pollution due to road traffic (emission of greenhouse gases (GHG) } \\
\text { calculated from the Copert } 4 \text { model) }\end{array}$ \\
\hline
\end{tabular}

FiguRE 2 - Selected indicators

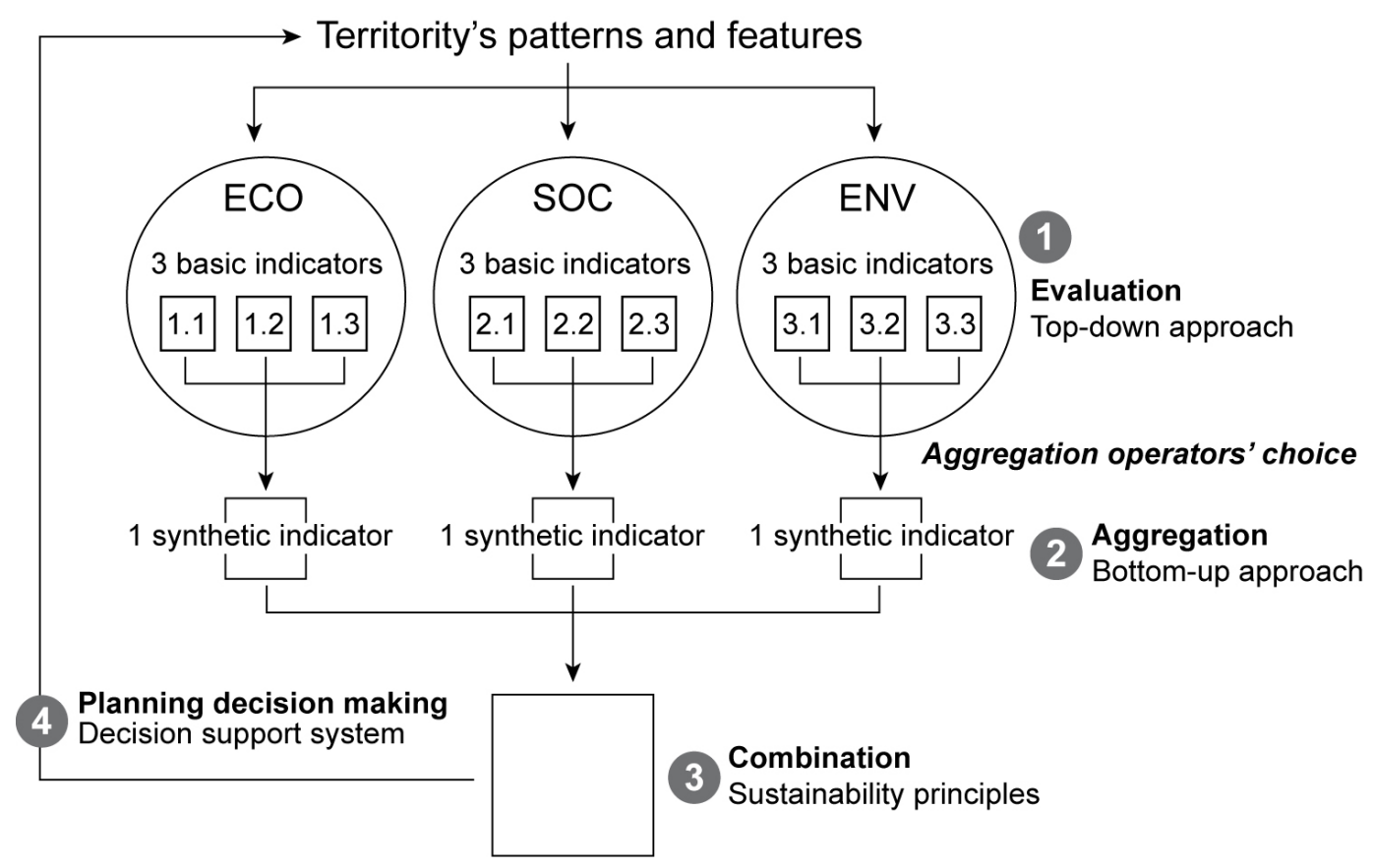

FiguRE 3 - General methodological framework 

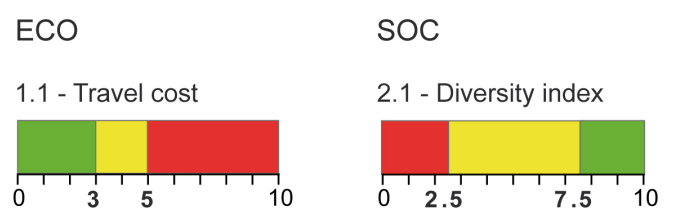

ENV

\section{2 - Transport perf.}

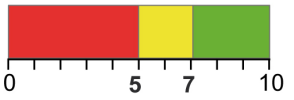

2.2 - Unemployment index

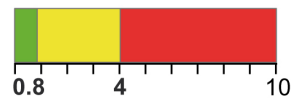

1.3 - Jobs availability

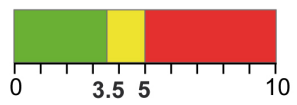

2.3. - Access to amenities
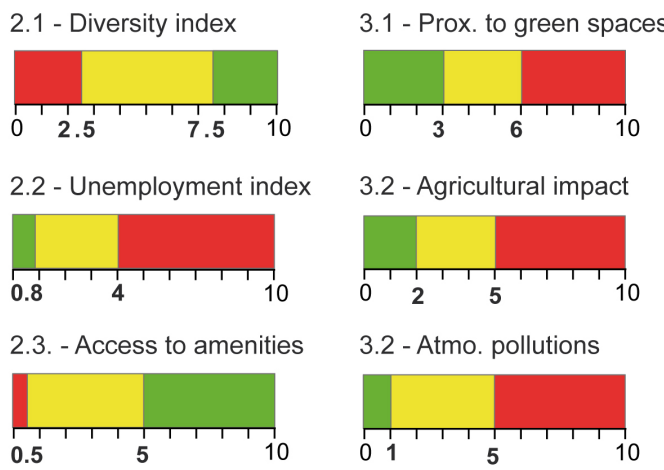

3.2 - Agricultural impact
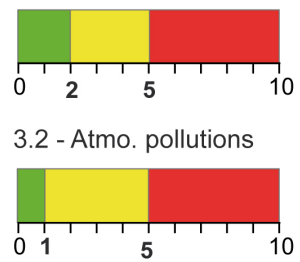

Evaluation

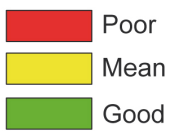

FIGURE 4 - Thresholds selected for evaluating the basic indicators

\subsection{Evaluation}

The first methodological step is to evaluate the indicators in order to assess how sustainable the territory is. But the nature of the nine indicators selected does not fit in with a simple binary logic characterizing the territory's cells as either "very good" or "very poor". Their evaluation corresponds more to a "gradual logic", in which each assessment depends on a threshold based on the indicator's nature and thematic significance for sustainable planning. To integrate this gradation, we refer to the principles of fuzzy logic ([Zad65]) which allows for "intermediate situations between everything and nothing" (i.e. "good" or "poor"). From this principle, each element must be associated with a greater or lesser degree of membership of a class within a defined range. In the case of Boolean values, for example, the end points of this range are 0 ("poor") and 1 ("good"). In our case, we choose to standardize all indicator values on a common scale ranging from 0 to 10 , where 0 and 10 are very poor or very good and all other values are located somewhere in-between good and poor, according to experts' appraisals of their significance for sustainability issues.

The values retained in the context of this paper are shown on Figure 4.For each indicator, the diagrams are developed based on an evaluation, presented here theoretically. In the case of a concrete application, this evaluation should be carried out by an expert in the fields covered by the indicators. From expert evaluations, the normalization mentioned above could be carried out on a scale from 0 to 10 . For instance, for the indicator of atmospheric pollution, a value approaching 10 would mean a high concentration of pollutants, and therefore a poor performance. Conversely, for the indicator of diversity, a low value tending towards 0 would mean a poor performance. The level of per- 


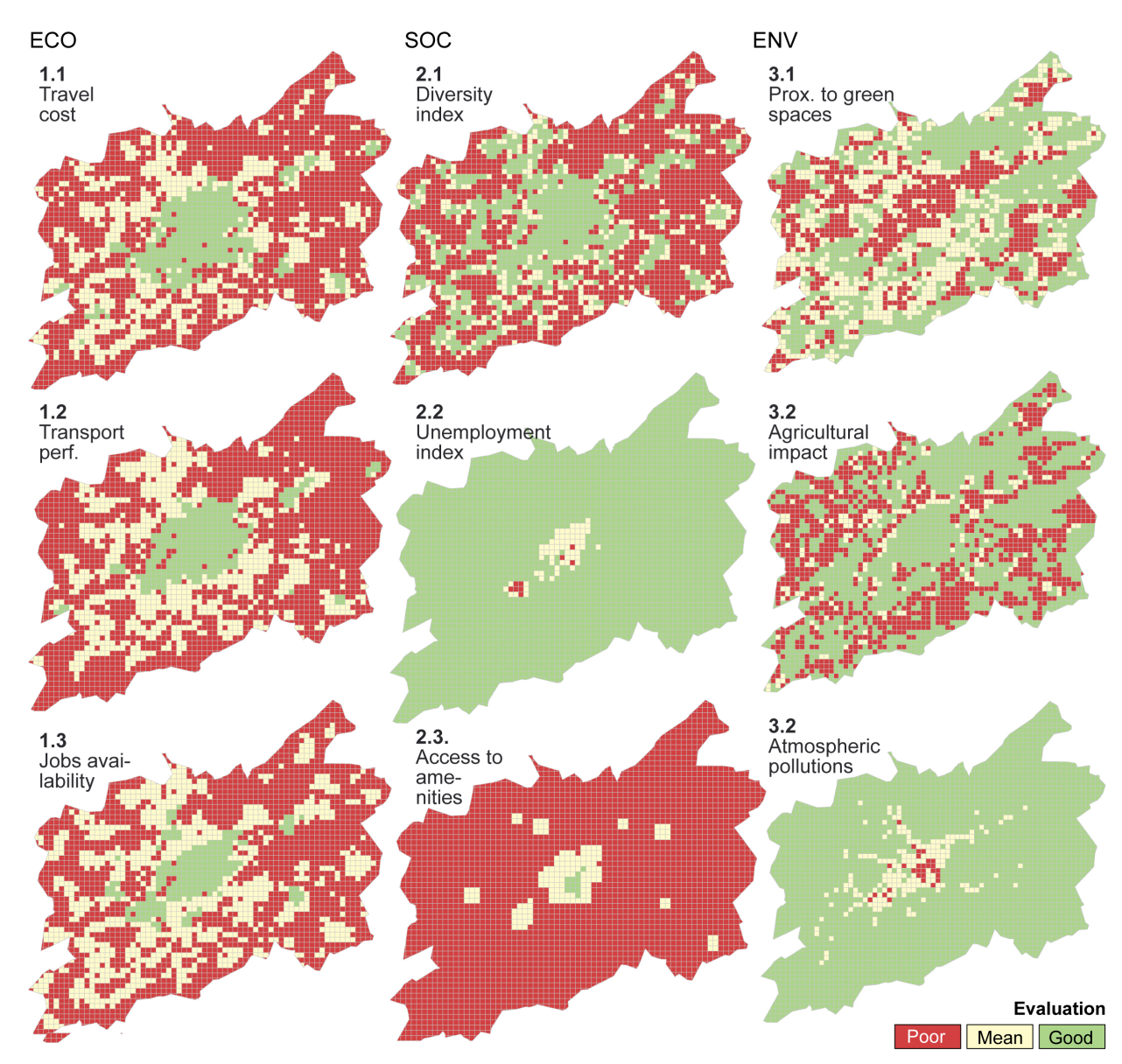

FIGURE 5 - Evaluation map : visualization of the basic indicators

formance could thus be defined by multiple categories; here we choose to use three : good (green), average (yellow), and poor (red). These three categories enable us to use a standard ordinal scale, inspired by methods such as the Lickert scale which measures the degree of agreement or disagreement of an individual (very low, low, moderate, high, and very high) ([YD10]). Here, the question is to measure how the indicator performs against the expectations of the planning actors. The scale is deliberately simplified and reduced to three categories, in order to make the tool more easily exploitable. The limits of these categories could also be collected from specific and local surveys by experts, stakeholders, and decision-makers to take into account the specificity of the territory. In this way, the evaluation process can integrate experts' viewpoints and scientific measures of the phenomena, based on their expected impact on territorial sustainability. An example of such impacts is given in Figure 5 representing each indicator's evaluation within $400 \mathrm{~m}$ cells. 
At this stage, the combination of different indicators for a comprehensive analysis of the sustainability of the territory remains poorly considered and cannot take into account the complementary character of territorial performances and the decision makers' opinions about good planning and investments practices and strategies. As shown in Figure 5, the indicators' evaluations form a basic set of results but they remain difficult to read and to handle in an operative way.

\subsection{Aggregation}

The aggregation of basic indicators into synthetic indicators raises the question of the weight and value of each basic indicator. As already mentioned in section 1.2., this aggregation step is the subject of much research. Many methods exist, using different approaches, notably synthetic approaches such as AHP or outranking methods such as PROMETHEE or ELECTRE ([RPLM12]). Among these methods, which are complex to implement, a major difference can be found between the possibility of compensating or not for a disadvantage in terms of certain criteria by a great advantage in terms of another criterion ([Mun05]). The choice to be made here is already subjective and depends on the vision of sustainability of decision-makers ([RPLM12]). Our approach being part of the production of a tool that is easily exploitable by planners, we choose to use the simplest aggregation operators by resorting to arithmetic and geometric means.The three categories "good", "average", and "poor" are normalized with the respective values of 0,2 , and 4 (Figure 6). A simple method consists in synthesizing the three indicators $I$ using an arithmetic mean $(\bar{I})$, giving them equal weight with a possibility of reciprocal compensation. In our case, aggregation may then rely on the following operation :

$$
\bar{I}=\frac{1}{n} \sum_{i=1}^{n} I_{i}=\frac{I_{1}+I_{2}+I_{3}}{3}
$$

Nevertheless, in some cases, decision-makers can estimate that an evaluation cannot be positive when one indicator at least is negative (e.g. air pollution). It will then be more appropriate to assign an eliminatory value to each basic indicator. These different options lead to the use of different aggregation operators ([Tan00]) such as geometric mean $\left(\bar{I}^{g}\right)$ or weighted mean $\left(\bar{I}^{w}\right)$ : 

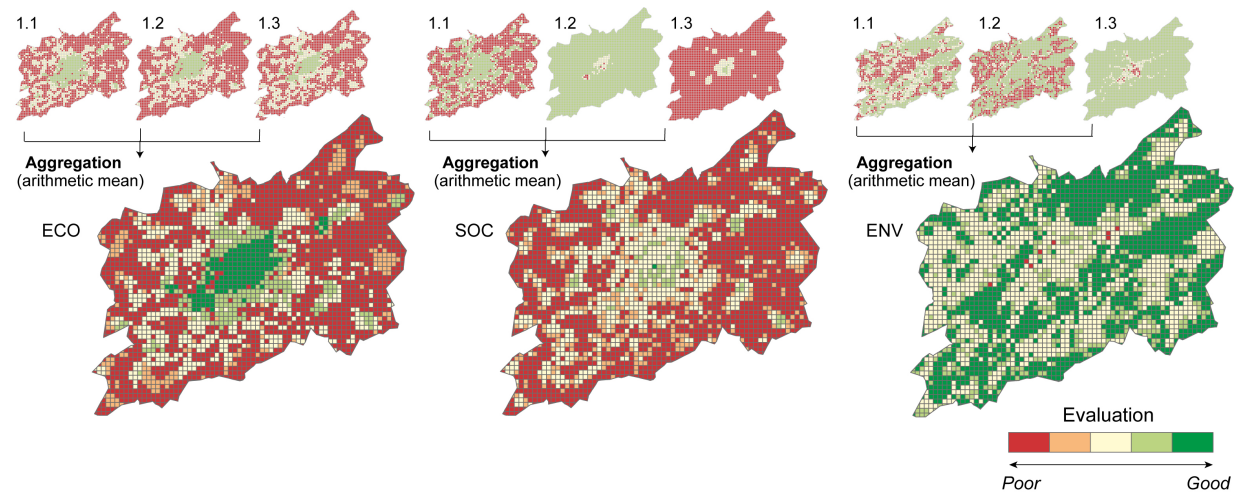

FIGURE 6 - Aggregation map : visualization of the synthetic indicators

$$
\begin{gathered}
\bar{I}^{g}=\sqrt[n]{\prod_{i=1}^{n} I_{i}}=\sqrt[3]{I_{1} \cdot I_{2} \cdot I_{3}} \\
\bar{I}^{w}=\frac{\sum_{i=1}^{n} \alpha_{i} \cdot I_{i}}{\sum_{i=1}^{n} \alpha_{i}}=\frac{\alpha_{1} \cdot I_{1}+\alpha_{2} \cdot I_{2}+\alpha_{3} \cdot I_{3}}{1}
\end{gathered}
$$

In the example above, which is an illustrative case of a general protocol, we use the arithmetic mean $(\bar{I})$ as an aggregation operator to calculate the results presented on Figure 6. This figure shows the aggregation of the $3^{*} 3$ indicators in each sphere (ECO, SOC, ENV) of sustainability. During the discussion (section 5), we will quickly analyze the opportunity of replacing arithmetic mean by geometric or weighted means to improve the eliminatory dimension of the aggregation. Other aggregation methods based on more complex operators than the RMS or OWA operator ([Tan00]) could obviously be considered, although their complexity would be a difficulty in terms of decision-makers actually handling this tool.

\subsection{Combination}

Having designed a synthetic indicator for each of the spheres, the next step is to combine them to assess the overall performance of each part of the territory. Following the main principles of sustainable development that requires a balance between the economic, social, and environmental spheres, we start from the point that each sphere must have equal weight : $(1 / 3)$ $+(1 / 3)+(1 / 3)=1$. The purpose is then to identify the performance of different areas, so as to deduce the compensations necessary to achieve a 
good balance between each sphere, capable of meeting the requirements of sustainable development.

From the values of the three synthetic indicators, a threshold can be determined to assess the performance of each cell, as described in figure 7. This threshold is established according to stakeholders' opinions and viewpoints, but the cells' performance remains based on the diagram from the Brundtland Report, which identifies different levels of combinations (from a to $G$ ) and assumes that the highest level of sustainability $(G)$ is reached when the three synthetic indicators are considered to be "good", that is, when the value of each indicator is between 3 and 4. For example, if a cell is associated with a value greater than 3 for the three indicators, it will be categorized as a "sustainable" (G) cell (white), combining a good performance in all three spheres. If a value greater than 3 is available for the environmental sphere only, it will be categorized as an "environmental" cell (green).

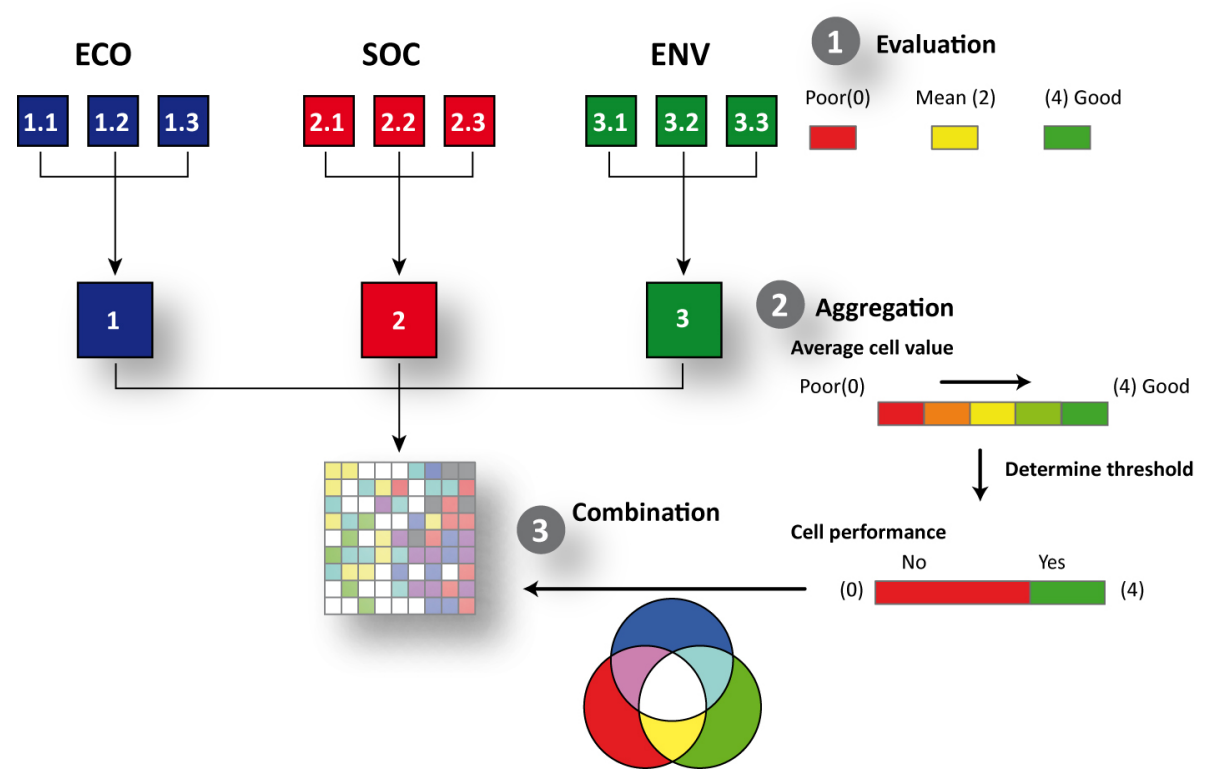

FIGURE 7 - Methodology of evaluation and aggregation

After this combination, each cell is categorized according to its level of sustainability. It should be noted that the method used in the previous stage (section 3.2.) to aggregate the basic indicators has a direct impact on the categorization of cells after combination : the decision of stakeholders to promote a particular indicator, or to associate eliminatory values with the evaluation, will lead to different results, as will be shown in the discussion. 


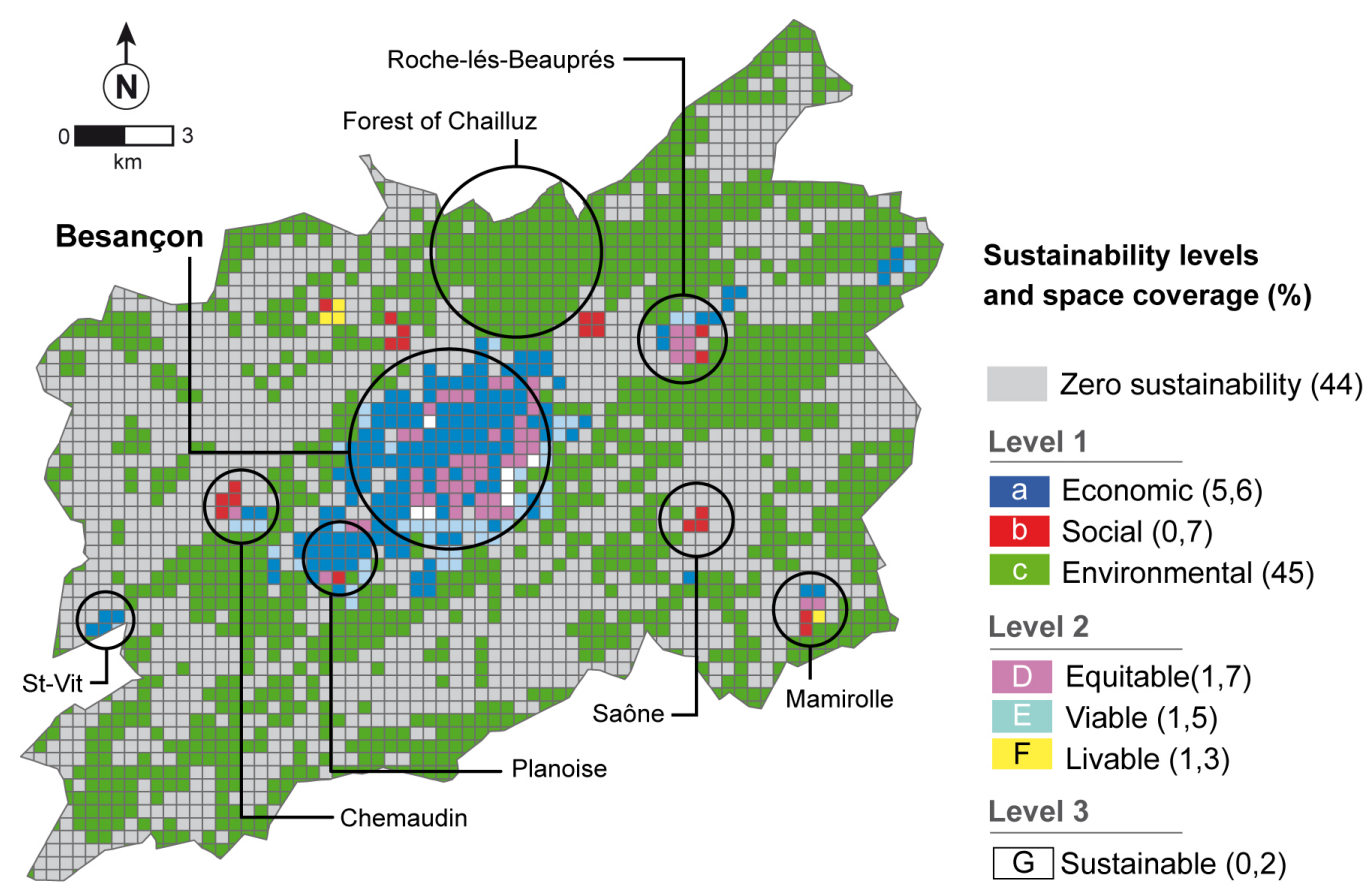

FiguRE 8 - Final Map : Greater Besançon sustainability levels after combination

\section{Results}

From this methodological approach, we can ultimately map the main results, i.e. the combinations of sustainability of the study area, measured within 400 $\mathrm{m}$ cells (Figure 8). Results show that high performance areas are very rare ( $0.2 \%$ combining more than two spheres) and that most of the cells are only associated with one sustainable criterion $(51.83 \%)$. The distribution of the cells presents a net imbalance for two of them : the "environmental" category (c) (45\%) and the "zero sustainability" category which does not include any combination, i.e. has no sustainable aspect (44\%). For other categories, the map shows that category (a) (economic) stands with $5.6 \%$, and that all others represent less than $2 \%$. Maximal sustainability category $(G)$ is the least represented with only seven cells $(0.2 \%)$. In total, cells combining one sphere or more represent just over half of the total area (55\%) and are mainly located in populated districts. Conversely, cells without any sustainable capacity are mostly uninhabited or sparsely populated (rural areas) and are usually remote from green amenities. Focusing on the spatial distribution of the sustainability categories obtained, the final map (Figure 8) shows spatial distributions that seem geographically structured into relevant districts of 


\begin{tabular}{l|c|} 
Type of combination & Percentage \\
\hline No combination & $\mathbf{4 4}$ \\
\hline One combination & $\mathbf{5 1 . 3}$ \\
a. Economic & 5.6 \\
b. Social & 0.7 \\
c. Environmental & 45 \\
\hline Two combinations & $\mathbf{4 . 6 1}$ \\
D. Equitable & 1.7 \\
E. Viable & 1.5 \\
F. Livable & 1.3 \\
\hline Three combinations & $\mathbf{0 . 2}$ \\
G. Sustainable & 0.2 \\
\hline Total combinations & $\mathbf{5 6}$
\end{tabular}

TABLE 1 - Greater Besançon : levels of sustainability

Great Besançon when compared with land use (figure 1) :

- Cells grouped in category (c) (environmental sphere) logically appear to be located in and around woodlands (especially the Forest of Chailluz to the north of the city)

- Periurban centers and villages (e.g. St-Vit, Mamirolle, Franois, Rocheles-BeauprÈs, etc.) appear more satisfactory in terms of combinations of criteria and can clearly be identified on the map.

- Concerning the central city of Besançon, we observe the emergence of cells corresponding to the equitable category (D), combining good economic and social performances.

- On the south side of the city, corresponding to the first forested foothills of the Jura mountains, viable cells (E) combine good economic performance and environmental advantages.

- In Besançon, Urban areas bordered by forest usually contain the cells which provide a maximum sustainability $(\mathrm{G})$.

- Other parts of the city of Besançon are usually economically powerful (category (a)) with good access to jobs and efficient transportation networks.

- Category (b) is located almost exclusively in peri-urban spaces and corresponds to cells characterized by good social indicators, but that are less attractive than Besançon in terms of access to jobs and transport networks.

- The working-class district of Besançon (Planoise) has good economic potential due to its geographical position but is at a disadvantage in the social sphere, because of social segregation 
These results confirm both intuitive and observed realities of Greater Besançon, and seem to make the method credible. After the aggregation and combination steps, the method leads to the identification and the location of coherent and representative areas. Logically, the cells associated with satisfactory combinations in all three spheres are located in urban areas, near green amenities, but they are very scarce. In the light of this analysis, we can conclude that sustainable areas (comprising one or more spheres) are urban areas with high densities of population and human activities, and which benefit from proximity to green amenities. But such a primary conclusion obviously raises several questions and has its limits.

\section{Discussion}

The main methodological limitation of the approach obviously concerns the scale of the sustainability analysis. In order to reduce the imbalance between the different categories observed in 3.2, and for the reasons explained in 2.1, it has been chosen to consider space within cells of $400 \mathrm{~m}$. But it is clear that, at this scale, sustainability (Category $(\mathrm{G})$ ) cannot be found in every cell and it would be aberrant to implement economic activities, social services, or green spaces everywhere to offset such local "gaps". It is thus self-evident that relevant thinking about compensatory measures must be conducted at the scale of the whole territory in order to ensure the global sustainability outlined in the introduction. It seems obvious that this paper presents a relevant approach for feeding this reflection from local measures of performance, but it also raises two major questions about sustainability principles. First, the scale of analysis must be carefully and cautiously determined to ensure a relevant evaluation of the overall sustainability. While the method was successfully applied to $400 \mathrm{~m}$ cells, it can also be used at other scales. As shown in Figure 9, these other scales highlight different territorial performances depending on the level of analysis, and can lead to different planning decisions and actions. For instance, a transformation at the local level (400 m cells) can change the performance of several cells, which may imply a modification in the performance at the global level $(3600 \mathrm{~m})$. In this example, a cell with a good economic performance is transformed into an equitable cell, combining good economic and social performances. The decomposition of the study area at different levels can clearly act, then, as a means to make it easier to strike a good balance, but it is also very confusing when it comes to making an unbiased assessment. Consequently, a multi-scalar approach appears essential. As shown in other research ([YDD15]), sustainability must be assessed across 

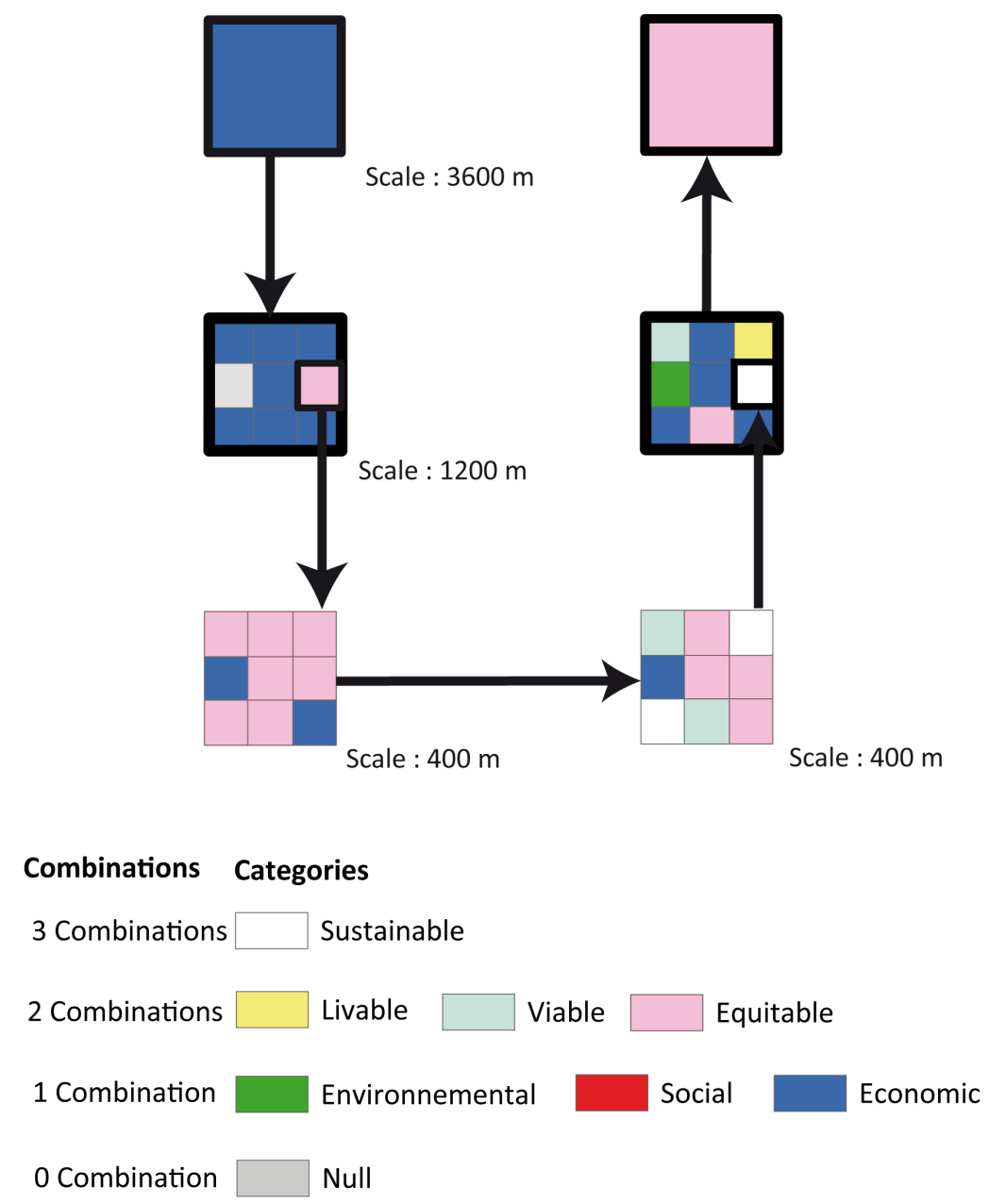

FIGURE $\boldsymbol{9}$ - Scales of evaluation: a theoretical example

different scales. But beyond the question of the scale of analysis and intervention, the problem of the scale of sustainability in itself remains : How will a local development impact its neighborhood? How is a global sustainable policy to be devised by interleaving different levels of intervention ([DYB14]).

Second, the method directly questions the equality between the three spheres promoted by the Brundtland Report. This equality is fiercely criticized at present by some anti-globalization movements or proponents of de-growth ([Sau07]; Bru04] [Lat06]), who believe that social and economic aspects must be subordinated to environmental protection. Conversely, others may favor an approach in which the economy takes precedence. These different political approaches lead us to consider "strong sustainability" or "low sustainability" ([Tur92]). In any case, the equivalence between the three spheres 
is replaced by subordination to the sphere favored by the stakeholder's vision. This subordination, which substitutes for equality, can of course be methodologically integrated by modifying the weight of the three spheres previously considered equal in the evaluation process, but this weighting must be clearly defined before undertaking the method.

Beyond the methodological aspects, these two questions lead to the discussion being centered on the ideological aspects of decision-making and their impact on planning choices related to sustainability. As said above, the concept of "sustainability" can be considered in different ways. Consequently, the choices made to weight each indicator should also make it possible to produce different results by using different operators, as shown in figure 11. In this figure, the clearest difference occurs between the geometric mean (see formula (2)) and the arithmetic mean (see formula (1)). Logically, assigning an eliminatory value makes the evaluation much more stringent. In this case, only the spaces corresponding to the urban center perform satisfactorily. Important nuances and real differences can also be seen when a weighted mean is used. We can see that the segregation linked to unemployment will clearly highlight the working-class district of Planoise. Figure 11 actually provides a concrete example of the importance of the choices of policy-makers and experts. The perception of sustainability and the inevitable associated bias may therefore have a significant impact on decision-making. Possible compensations are somehow already influenced by the decision-maker's initial choices. It therefore seemed important to study the impact of these initial choices on the final result. Here we present results obtained from synthetic indicators after the variable weightings presented previously. Of course, there is a multitude of possible results that cannot be represented here. By way of illustration, we have selected three final outcome maps influenced by synthetic indicators designed to favor one of the basic indicators. In the aggregation process, this indicator has a weighting of $50 \%$ (the other two of $25 \%$ ).We present three scenarios here (named intuitively and arbitrarily, therefore questionably, given the preferred indicators) the results of which differ (Figure 10). In this figure, for each scenario, the basic indicator given precedence in each of the three spheres is weighted up to $50 \%$ during the aggregation in the synthetic indicator.

- a "welfare" scenario : promotion of lower cost of travel, good access to urban amenities and proximity to green spaces;

- an "ecologist" scenario : in every sphere, the privileged indicators are those of atmospheric pollution, the performance of public transit, and diversity;

- an "efficiency" scenario : promotion of access to jobs, preservation of agricultural areas and weak segregation linked to unemployment. 
TABLE 2 - Proportion of cells in each category according to the choice of weighting

\begin{tabular}{l|llllllll} 
Cat. & Confort & $\%$ & Ecolo. & $\%$ & Efficace & $\%$ & Standard & $\%$ \\
\hline 0 & 1708 & 58,88 & 1308 & 45,09 & 1363 & 46,98 & 1289 & 44,43 \\
1 & 0 & 0,00 & 5 & 0,17 & 6 & 0,21 & 7 & 0,24 \\
2 & 0 & 0,00 & 4 & 0,14 & 4 & 0,14 & 4 & 0,14 \\
3 & 24 & 0,83 & 32 & 1,10 & 17 & 0,59 & 45 & 1,55 \\
4 & 9 & 0,31 & 53 & 1,83 & 38 & 1,31 & 51 & 1,76 \\
5 & 933 & 32,16 & 1314 & 45,29 & 1321 & 45,54 & 1318 & 45,43 \\
6 & 0 & 0,00 & 21 & 0,72 & 27 & 0,93 & 21 & 0,72 \\
7 & 227 & 7,82 & 164 & 5,65 & 125 & 4,31 & 166 & 5,72
\end{tabular}

The results are shown in Tab. 2, where the "baseline" scenario corresponds to the final results presented in section 4 . We can see that variations exist but are still limited. The comparison of the number of cells belonging to each category shows a rather limited variation. The number of cells that do not change categories comes to 2209 cells out of 2901 or $78.9 \%$. Variations do occur therefore, but they are limited variations for the whole territory studied. The question, therefore, is whether to focus more on the issue of aggregation, i.e. on the calibration of the process that we propose. In other words, does the question of weighting affect the final results so much that it becomes the central question of the methodological process? We are tempted to answer negatively.

Theses choices are obviously not trivial and clearly affect the results; but we assume that the methodology proposed here is capable of managing a wide range of opinions, and that it ultimately provides better answers to fundamental planning questions: How are decisions made and who makes them? Many reflections about these questions are currently being conducted in the literature on sustainable planning issues in order to establish social norms for guiding stakeholders and for making meaningful policy decisions and actions ([VKM $\left.{ }^{+} 16\right]$ ). For instance, interviews or survey techniques can help calibrate the method and take into account actors' opinions about indicator weightings or specific definitions of local sustainability.

\section{Conclusion}

In conclusion, we provide a prototype of a decision-support tool based on a method that seeks to rely on the complementary character of general (sustai- 


\section{Welfare}

Eco: Travel post

Soc: Access to amenities

Env: Prox. to green spaces

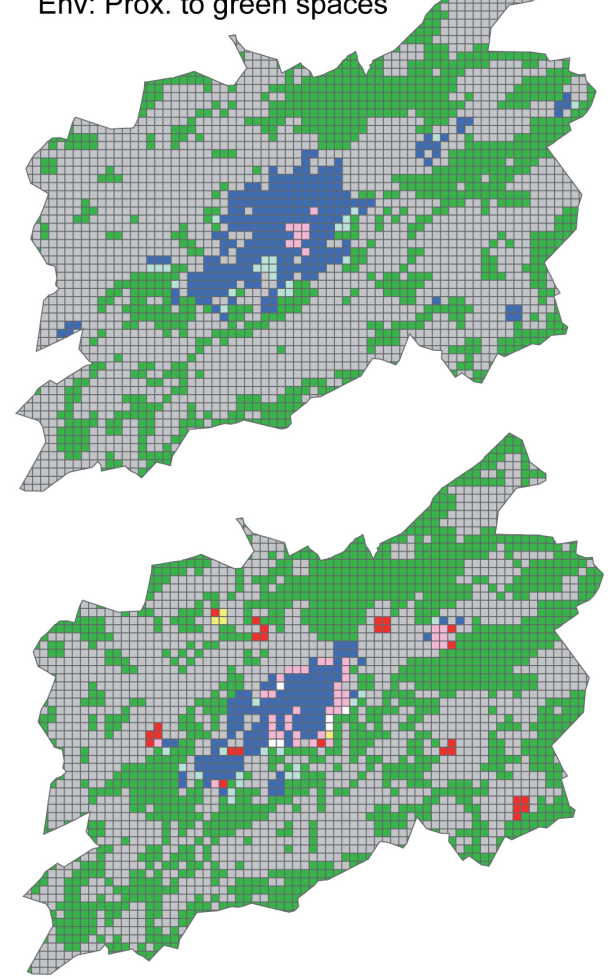

Efficiency

Eco: Jobs avaibility

Soc: Unemployment

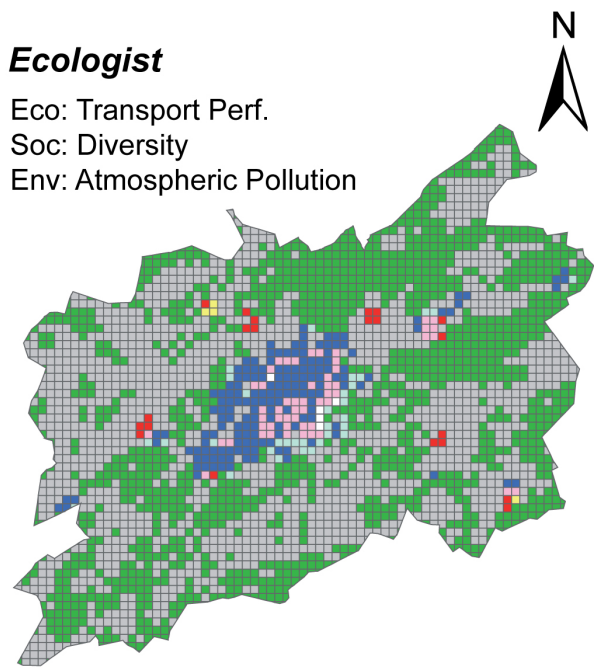

Sustainability levels and space coverage

Zero sustainability

Level 1

a Economic

b Social

c Environmental

Level 2

D Equitable

E Viable

F Livable

Level 3

G Sustainable

Env: Agricultural impact

FIGURE 10 - Variation of the final results according to scenarios favoring different indicators. 


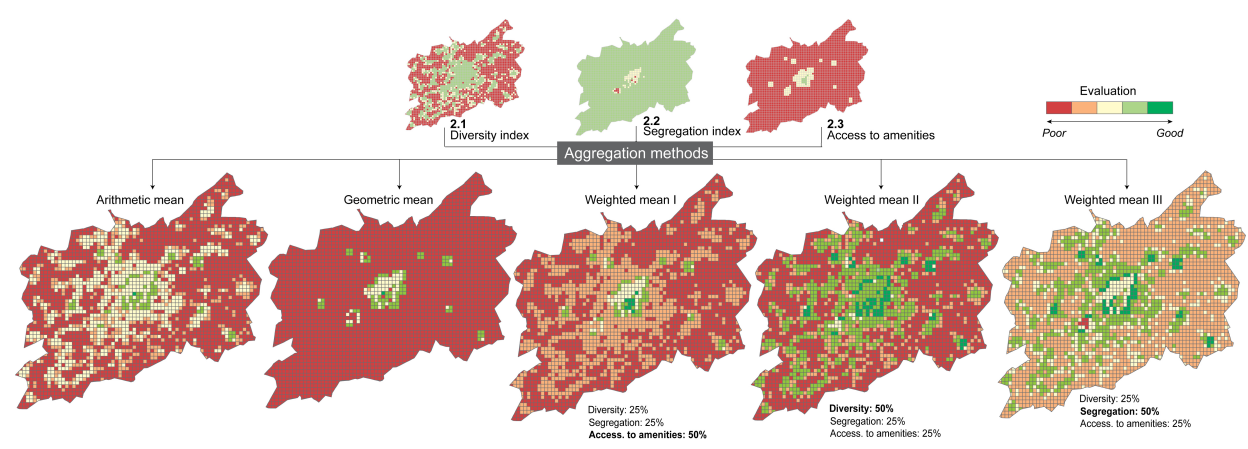

FIGURE 11 - Examples of weightings for a social synthetic indicator

nability principles) and local (stakeholders' opinions) approaches. After normalization and evaluation of various selected indicators, their aggregation is based on a participatory approach and yields synthetic indicators. These synthetic indicators can be very different depending on the chosen aggregation process, showing the importance and the influence of stakeholders' opinions. Completing the results by such a methodological approach could contribute to consolidating the quality of this work $\left(\left[\mathrm{HHU}^{+} 18\right]\right.$; [GLC17]; [LZJ14]. The combination of synthetic indicators can be displayed as a map evaluating the study area in relation to sustainability requirements. This map produces a new global indicator for evaluating the overall performance of each part of the territory and is the main innovative feature of this work.

But even if the map may be associated with an operational decision-making tool for compensatory measures and policies, in practice it raises the question of the scale and balance of sustainability. In addition, its operability for planning issues requires two approaches to be articulated that may appear contradictory but that we actually view as complementary. The first of these is a general approach that can provide a universal method that is transposable to other situations and leads to "sustainability labels". Being based on standard indicators it is easily transferable and can be used for comparing territories and different kinds of policies. The second is a territorial and participative approach, based on an evaluation using methods and co-produced tools shared between stakeholders and actors, and adapted to each territory-specific case. Indeed, in the broad objectives of sustainability development ([Bru87]), it is currently common knowledge that sustainability is not to be measured by standardized criteria for every territory, but involves specific characteristics and potentials of each study area ([Wat16]). To this end, the concept of metaplanning, first developed in the 1970's with to promote long-term business strategies ([Ems78]) and recently adapted to urban planning policies ([Cam14]), seems to provide a useful framework wi- 
thin which to identify the actors, activities, tools, and methods involved in decisions about planning, in order to organize and optimize decision-making over the long term, and to make it as operative as possible.

Given the complexity of coming up with a unanimous valid definition of sustainable development, there is no question here of proposing a magic formula for definitively evaluating the sustainability of a territory on a strictly scientifically neutral basis $\left(\left[\mathrm{VKM}^{+} 16\right]\right)$. The method must merely be thought of as a new protocol for use in planning models, to make their results more readable, to synthesize the multitude of data and indicators they produce, and finally to achieve greater cohesion among stakeholders. The main research perspective arising from our work would be to make a comparison with other methods of evaluating the sustainability of territories, especially those mentioned in section 1.2 (AHP, ELECTRE, TOPSIS, etc.). In this way it would be possible to compare the application of the different methods to a single territory and to analyze whether these methods could be transposed to other territories.

\section{Références}

$\left[\mathrm{ABF}^{+} 14\right]$ J.P. Antoni, O. Bonin, P. Frankhauser, H. Houot, J.P. Nicolas, C. Thierry, L. Tomasoni, and G. Toillier, F.and Vuidel. Vilmodes, villes et mobilites durables, rapport de recherche. Technical report, PREDIT, 2014.

[AL08] A. Agger and K. Löfgren. Democratic assessment of collaborative planning processes. Planning Theory, 7(2) :145-164, 2008.

[ALV16] J.P. Antoni, N. Lunardi, and G. Vuidel. Simuler les mobilités individuelles-les enjeux de 1,Äôinformation géographique. Revue Internationale de Géomatique, 26(2) :237-262, 2016.

[AMJ17] M. Andreasen and L. Møller-Jensen. Access to the city : Mobility patterns, transport and accessibility in peripheral settlements of dar es salaam. Journal of Transport Geography, 62 :20-29, 2017.

[Ant11] J.P. Antoni. Modeliser la ville. Economica, 2011.

[APL18] S. Allain, G. Plumecocq, and D. Leenhardt. Spatial aggregation of indicators in sustainability assessments : Descriptive and normative claims. Land Use Policy, 2018. 
[AV10] J.-P. Antoni and G. Vuidel. Mobisim : un modèle multi-agents et multi-scalaire pour simuler les mobilités urbaines, 2010.

[BH08] F. Burstein and C. W. Holsapple. Handbook on decision support systems 2 : variations. Springer Science \& Business Media, 2008.

[BM08] S. Bell and S. Morse. Sustainability indicators : measuring the immeasurable? Earthscan, 2008.

$\left[\mathrm{BMP}^{+} 18\right]$ A. Boggia, G. Massei, E. Pace, L. Rocchi, L. Paolotti, and M. Attard. Spatial multicriteria analysis for sustainability assessment : A new model for decision making. Land Use Policy, 71 :281 $292,2018$.

[Bou10] A Boutaud. Les indicateurs de développement durable à 1,Äôéchelle des territoires. Zuideau B., Développement durable et territoire, Villeuneuve d,ÄôAsq, Presses du Septentrion, 2010.

[Bru87] G. H. Brundtland. Report of the World Commission on environment and development :" our common future.". United Nations, 1987.

[Bru04] S. Brunel. Le développement durable. Paris, PUF, collection Quesais-je, 2004.

[BT04] I. Benenson and P. M. Torrens. Geosimulation : Automata-based modeling of urban phenomena. John Wiley \& Sons, 2004.

[Cam14] M. Campagna. Geodesign from theory to practice : From metaplanning to 2nd generation of planning support systems. Tema. Journal of Land Use, Mobility and Environment, 2014.

[CCK14] M. Cinelli, S. Coles, and K. Kirwan. Analysis of the potentials of multi criteria decision analysis methods to conduct sustainability assessment. Ecological Indicators, 46 :138-148, 2014.

[d'A94] Charte d'Aalborg. Charter of european cities and towns towards sustainability. Article presenté à European Conference on Sustainable Cities \& Towns, Aalborg, Denmark, 1994.

[DY15] F. Dur and T. Yigitcanlar. Assessing land-use and transport integration via a spatial composite indexing model. International Journal of Environmental Science and Technology, 12(3) :803$816,2015$. 
[DYB14] F. Dur, T. Yigitcanlar, and J. Bunker. A spatial-indexing model for measuring neighbourhood-level land-use and transport integration. Environment and Planning $B$ : Planning and Design, 41(5) :792-812, 2014.

[Ems78] J.R. Emshoff. Planning the process of improving the planning process : A case study in meta-planning. Management Science, 24(11) :1095-1108, 1978.

$\left[\mathrm{FDM}^{+} 06\right]$ E.D.G. Fraser, A.J. Dougill, W.E. Mabee, M. Reed, and P. McAlpine. Bottom up and top down : Analysis of participatory processes for sustainability indicator identification as a pathway to community empowerment and sustainable environmental management. Journal of environmental management, 78(2) :114-127, 2006.

[FP12] V. Ferretti and S. Pomarico. Integrated sustainability assessments : a spatial multicriteria evaluation for siting a waste incinerator plant in the province of torino (italy). Environment, development and sustainability, 14(5) :843-867, 2012.

[FP13] V. Ferretti and S. Pomarico. Ecological land suitability analysis through spatial indicators : An application of the analytic network process technique and ordered weighted average approach. Ecological Indicators, 34 :507-519, 2013.

[GC08] G. A Giff and J. Crompvoets. Performance indicators a tool to support spatial data infrastructure assessment. Computers, Environment and Urban Systems, 32(5) :365-376, 2008.

$\left[\mathrm{GDJ}^{+} 13\right]$ A. González, A. Donnelly, M. Jones, N. Chrysoulakis, and M. Lopes. A decision-support system for sustainable urban metabolism in europe. Environmental Impact Assessment Review, $38: 109-119,2013$.

[GGB $\left.{ }^{+} 16\right]$ Ottomano Palmisano G.., K. Govindan, A. Boggia, R.V. Loisi, A. De Boni, and R. Roma. Local action groups and rural sustainable development. a spatial multiple criteria approach for efficient territorial planning. Land use policy, 59 :12-26, 2016.

[GLC17] Lineker M. Goulart, C., L.C. Lange, and H.M.G. Coelho. Multicriteria decision making to support waste management : A critical review of current practices and methods. Waste Management $\&$ Research, 35(1) :3-28, 2017. 
$\left[\mathrm{HHU}^{+} 18\right]$ H. Haider, K. Hewage, A. Umer, R. Ruparathna, G. ChhipiShrestha, K. Culver, M. Holland, J. Kay, and R. Sadiq. Sustainability assessment framework for small-sized urban neighbourhoods : An application of fuzzy synthetic evaluation. Sustainable cities and society, $36: 21-32,2018$.

[HOC07] M. Huby, A. Owen, and S. Cinderby. Reconciling socio-economic and environmental data in a gis context : an example from rural england. Applied Geography, 27(1) :1-13, 2007.

[HWY15] L. Huang, J. Wu, and L. Yan. Defining and measuring urban sustainability : a review of indicators. Landscape Ecology, 30(7) :1175-1193, 2015.

[KLM15] R. Kitchin, T. P Lauriault, and G. McArdle. Knowing and governing cities through urban indicators, city benchmarking and realtime dashboards. Regional Studies, Regional Science, 2(1) :6-28, 2015 .

[KRB10] R. Kühne, M. Ruhé, and X. Bei. Sustainable mobility and sustainable transport for medium-size cities in china. In Traffic and Transportation Studies 2010, pages 27-36. 2010.

[Lat06] S. Latouche. Le pari de la décroissance. Fayard, 2006.

$\left[\mathrm{LLH}^{+}\right.$09] F. Li, X. Liu, D. Hu, R. Wang, W. Yang, D. Li, and D. Zhao. Measurement indicators and an evaluation approach for assessing urban sustainable development : A case study for china's jining city. Landscape and Urban Planning, 90(3) :134-142, 2009.

$\left[\mathrm{LSW}^{+} 04\right]$ K. Lautso, K. Spiekermann, M. Wegener, I. Sheppard, P. Steadman, A. Martino, R. Domingo, and S. Gayda. Propolis. Planning and Research of Policies for Land Use Transport for Increasing Urban Sustainability, Final Report, 2004.

[LZJ14] A. Ligmann-Zielinska and P. Jankowski. Spatially-explicit integrated uncertainty and sensitivity analysis of criteria weights in multicriteria land suitability evaluation. Environmental Modelling \& Software, 57 :235-247, 2014.

[Mal99] J. Malczewski. GIS and multicriteria decision analysis. John Wiley \& Sons, 1999. 
[Mal06] J. Malczewski. Gis-based multicriteria decision analysis : a survey of the literature. International Journal of Geographical Information Science, 20(7) :703-726, 2006.

$\left[\mathrm{MRP}^{+} 14\right]$ G. Massei, L. Rocchi, L. Paolotti, S. Greco, and A. Boggia. Decision support systems for environmental management : A case study on wastewater from agriculture. Journal of Environmental Management, 146 :491-504, 2014.

[Mun05] G. Munda. ,Äúmeasuring sustainability,Äù : a multi-criterion framework. Environment, Development and Sustainability, 7(1) :117-134, 2005.

[MWT13] H. J Miller, F. Witlox, and C.P. Tribby. Developing contextsensitive livability indicators for transportation planning : a measurement framework. Journal of Transport Geography, 26 :51-64, 2013.

[PAMS04] J. Pope, D. Annandale, and A. Morrison-Saunders. Conceptualising sustainability assessment. Environmental impact assessment review, 24(6) :595-616, 2004.

[Ree05] M.S. Reed. Participatory rangeland monitoring and management in the Kalahari, Botswana. PhD thesis, University of Leeds, 2005.

[R.F69] Tomlinson R.F. A geographic information system for regional planning. Journal of Geography (Chigaku Zasshi), 78(1) :45-48, 1969.

[RFD06] M.S. Reed, E.D.G. Fraser, and A.J. Dougill. An adaptive learning process for developing and applying sustainability indicators with local communities. Ecological economics, 59(4) :406-418, 2006.

[Roy85] B. Roy. Méthodologie multicritère d" aide à la décision. Economica, 1985.

[RPLM12] H. V Rowley, G. M. Peters, S. Lundie, and S.J. Moore. Aggregating sustainability indicators : beyond the weighted sum. Journal of Environmental Management, 111 :24-33, 2012.

[Saa90] T.L. Saaty. How to make a decision : the analytic hierarchy process. European journal of operational research, 48(1) :9-26, 1990. 
[Sau07] L. Sauvé. L, Äôéquivoque du développement durable. Chemin de traverse, $4: 31-47,2007$.

[Tan00] C. Tannier. Les Localisations commerciales de détail en milieu urbain. Mieux connâ̂tre, par la modélisation, pour mieux aménager. Besançon : Université de Franche-Comté. PhD thesis, thèse de géographie, sous la direction de M. Le Berre, 2000.

[THS $\left.{ }^{+} 16\right]$ C. Tannier, J. Hirtzel, R. Stephenson, A. Couillet, G. Vuidel, and S. Youssoufi. Conception and use of an individual-based model of residential choice in a planning decision process. feedback from an experimental trial in the city of besançon, france. Progress in Planning, 108 :1-38, 2016.

[Tim03] H. Timmermans. The saga of integrated land use-transport modeling : how many more dreams before we wake up? In Keynote paper, Moving through nets : The Physical and social dimension of travel, 10th International Conference on Travel Behaviour Research, Lucerna, www. ivt. baug. ethz. ch/allgemein/pdf/timmermans. pdf, 2003.

[Tur92] R. Turner. Speculations on weak and strong sustainability. 1992.

$\left[\mathrm{VKM}^{+} 16\right]$ A. Voinov, N. Kolagani, M. K. McCall, P.D. Glynn, M.E. Kragt, F. O. Ostermann, S.A. Pierce, and P. Ramu. Modelling with stakeholders-next generation. Environmental Modelling $\&$ Software, 77 :196-220, 2016.

[Wat16] V. Watson. Locating planning in the new urban agenda of the urban sustainable development goal. Planning Theory, 15(4) :435448, 2016.

[Weg94] M. Wegener. Operational urban models state of the art. Journal of the American planning Association, 60(1) :17-29, 1994.

[YD10] T. Yigitcanlar and F. Dur. Developing a sustainability assessment model : The sustainable infrastructure, land-use, environment and transport model. Sustainability, 2(1) :321-340, 2010.

[YDD15] T. Yigitcanlar, F. Dur, and D. Dizdaroglu. Towards prosperous sustainable cities : A multiscalar urban sustainability assessment approach. Habitat International, 45 :36-46, 2015. 
[YF15] C. Yamu and P. Frankhauser. Spatial accessibility to amenities, natural areas and urban green spaces : using a multiscale, multifractal simulation model for managing urban sprawl. Environment and Planning B : Planning and Design, 42(6) :1054-1078, 2015 .

[ZA08] P. Zhou and B.W. Ang. Indicators for assessing sustainability performance. Handbook of performability engineering, pages $905-$ 918, 2008.

[Zad65] L. A. Zadeh. Fuzzy sets, inform. Control, 8 :338-353, 1965. 